\title{
Is Business Creation the Mean or the End of Entrepreneurship Education? A Multiple Case Study Exploring Teaching Goals in Entrepreneurship Education ${ }^{2}$
}

\author{
Carlos Albornoz Pardo'
}

\begin{abstract}
Entrepreneurship education within higher education has experienced a remarkable expansion in the last 20 years (Green \& Rice, 2007). However, entrepreneurship education is still in its infancy; professors propose diverse teaching goals and radically different teaching methods. This represents an obstacle to development of foundational and consistent curricula across the board (Cone, 2008). This study was designed to understand entrepreneurship instructor's teaching goals. Results suggest that the group of instructors studied pursued two types of profoundly different teaching goals. Some of them were trying to teach how to start a successfully business while another group was trying to develop entrepreneurial skills. Those two types of teaching goals have important implications in terms of pre selection of students, the mandatory or voluntary character of the curriculum, and type of teaching methods used. For instance, if the goal is to create business, students should be selected according to the potential of their ideas, the regimen should be voluntary (students legitimately may want to become great employees), and business plan as teaching methods should be understood a mean rather than an end.
\end{abstract}

Keywords: entrepreneurship education; teaching goals; teaching methods; entrepreneurial skills; potential.

\footnotetext{
'Universidad del Desarrollo, Av. La Plaza, 680, Las Condes. Santiago, Chile. Phone: 02 23279205. Email: calbornoz@udd.cl.

${ }^{2}$ Este trabajo se ha realizado bajo el apoyo del Proyecto Fondecyt $\mathrm{N}^{\circ}$ III2I458 "The Effect of Obligatory Entrepreneurship Education on College Students".
} 


\section{Introduction}

Along with the accumulation of evidence supporting the role of entrepreneurship in economic development (Acs, 2002; Kuratko, 2005; Reynolds et al., 2005), governments have persisted in encouraging people to become entrepreneurs (Brannback \& Carsrud, 2009). In Australia, the Federal Government invested $\$ 2.9$ billion in 200 I to include a culture of entrepreneurship and innovation in the educational system (Jones, 2007). The Kauffman Foundation donated $\$ 40$ million in 2003 to make entrepreneurship education available across U.S. university campuses (Kauffman Foundation, 2009). In Chile, 4 million US dollars were allocated in 2011 to fund entrepreneurship education programs. These efforts tried to reproduce the conditions under which entrepreneurship emerges; one of these conditions is the existence of entrepreneurial skills among students and scientists (Phan \& Foo, 2004). In addition to the interest of governments, the rise of entrepreneurship programs has been fueled by an unprecedented student demand for an education that provides the skills needed to succeed in an increasingly divergent business environment (Cooper, Bottomley, \& Gordon, 2004). In response, educational institutions have implemented learning activities associated with entrepreneurship such as lectures on business concepts, business-planning competitions, interaction with practitioners, and networking events (Al-Laham, Souitaris, \& Zerbinati, 2007). As a consequence of an increasing demand, entrepreneurship education within higher education has experienced a remarkable expansion (Green \& Rice, 2007). In the U.S., the number of universities reporting courses in entrepreneurship grew from 300 in the early I980s to I,050 in 1990 (Dickson, Solomon, \& Weaver, 2008). The number of entrepreneurship courses that colleges and universities offer, grew from less than ten in 1970 (Kuratko, 2005) to over 2,000 in 2008 (Cone, 2008).

Even though energy and resources dedicated to study how entrepreneurship is taught, entrepreneurship education is still in its infancy (Carayannis, Evans, \& Hanson, 2003). Several reasons may explain why entrepreneurship education has shown little progress in term of finding what should inform teaching practice. Bechard \& Gregoire, (2005) identified some of those reasons: (a) the need of the field for legitimacy relegates entrepreneurship teaching to a secondary place, (b) entrepreneurship education does not generate the same professional rewards as research in business, (c) the difficulty in pursuing interdisciplinary research, and (d) the teaching is done mostly by non tenure track adjunct instructors are additional difficulties to advance entrepreneurship education. In addition to that, the appropriate content for entrepreneurship programs have remained under constant discussion (Gibb, 2002). Fiet (2000) thinks that an important reason underlying the different emphasis that entrepreneurship instructors show, it is the eclectic nature of entrepre- neurship as a discipline. With the exception of discovery/ idea generation, most topics included in entrepreneurship education comes from the established literature of other disciplines (Fiet, 2000). Motivated in overcoming some barriers related to the teaching practice, Professor Fiet gathered 18 instructors at the Rensselaer Polytechnic Institute to discuss the learning aspects of entrepreneurship education. The retreat's participants shared their syllabi to analyze the topics they covered. One of the conclusions of this meeting was that content covered was diverse and that entrepreneurship instructors are highly influenced by their own research streams when choosing content for their classes (Fiet, 2000). Six leading topical areas were identified as the content usually included in entrepreneurship classes: (a) strategy/competitive analysis, (b) managing growth, (c) discovery/idea generation, (d) risk and rationality, (e) financing, and (f) creativity. The range of contents considered important by those entrepreneurship instructors was diverse.

Fiet (2000) suggested that three possible elements could influence instructors' selection of content: (a) academic autobiography, (b) lack of theoretical rigor, and (c) entrepreneurship textbooks. Fifteen out of the eighteen instructors participating in the retreat used reading packets, which is a symptom that they are not satisfied with textbooks; however, there was little agreement on what should be included in the course-reading packet (Fiet, 2000).

There is abundant literature reporting that entrepreneurship instructors teach different things under the same umbrella of entrepreneurship courses (Van der Sluis, Van Praag, \& Vijverberg, 2008; Weaver, Dickson, \& Solomon, 2005). In spite of this shared diagnosis, little is know about the expected outcomes and intentions of entrepreneurship instructors. The purpose of this study was to explore and analyze in depth what entrepreneurship instructors wants students in their courses to learn. Before making any appraisal about the effectiveness of entrepreneurship education we need to understand what are the teaching goals of entrepreneurship educators and why they pursue those. The research question guiding this study was: How do higher education instructors select teaching goals to teach entrepreneurship?

\section{Method}

A multiple case study design was appropriate for this research because it facilitates understanding instructors' perspectives and actions related to their selection of goals. The population for this study consisted of college and university instructors who teach entrepreneurship. Alan Carsrud, one of the most cited authors in entrepreneurship (Reader \& Watkins, 2006), was the key informant to find the instructors for this study. 
The study utilized criterion and maximum variation sampling strategies (Patton, 200I). Criterion sampling involves selecting cases that meet predetermined criteria of importance (Patton, 200I). The criteria for inclusion in this study were (a) teaching at least one entrepreneurship course in one academic year, (b) teaching either at an engineering school or at a business school, and (c) holding a terminal degree. A criterion for exclusion is teaching only at the doctoral level. The reason to exclude instructors who teach at doctoral level only is that most doctoral programs are designed to develop research skills and not entrepreneurial skills which are the focus of this study. For the same reason, instructors in the sample need to be active as teachers and not solely as administrators who are no longer in the classroom, even though they might identify themselves as entrepreneurship instructors.

Three types of data were collected from each instructor: (a) documents, such as CVs and syllabi. (b) Surveys, such as the Teaching Goal Inventory (Angelo \& Cross, 1993) and (c) Interviews. Using a semi-structured guide, the participants were asked about their definitions of entrepreneurship, educational program, backgrounds, work experience, beliefs about entrepreneurial learning, and how they select teaching goals for an entrepreneurship course. Eight cases were included: four instructors who taught entrepreneurship at a business school and four instructors who taught entrepreneurship at an engineering school.

To analyze the data, a coding system was developed from the interview transcripts and documents. To develop a coding system, chunks of text that represent a concept or a theme were identified within transcripts and documents. Within and across case analysis was performed before to present conclusion to the key informant and to a committee of experts. The key informant revised each case draft. The analysis looked for patterns that provided information about teaching goals of entrepreneurship instructors.

In order to improve construct and internal validity, the study used several sources of data (interviews, Teaching Goals Inventory reports, CVs, and syllabi) (Merriam, 2002;Yin, 2003). In addition to that, rich descriptions of the participants and their experiences are provided to achieve external validity (Berg, 200I). Rich descriptions allowed the transfer of findings to other contexts. Finally, findings were compared with previous literature about how instructors selected teaching goals in other educational settings. Because this is a qualitative study, the intention was to be analytic and descriptive about the eight cases included rather than to generalize to all higher education entrepreneurship instructors.

\section{Literature Review}

As a field of study, entrepreneurship has been under permanent debate about what should be its subject of study (Brush, Manolova, \& Edelman, 2008) (Brush et al., 2008). Given the multidisciplinary field of entrepreneurship, the content covered in most entrepreneurship courses is far reaching. In an effort to provide a framework to classify entrepreneurship education goals, Jamieson (1984) proposed that teaching goals in entrepreneurship education should be organized into three major categories: (a) education about enterprises, (b) education for enterprise, and (c) education in enterprise. Education about enterprises deals with awareness creation and would educate students about theories of how businesses are created and managed. Education for enterprise deals with the possibility of having a career as an entrepreneur and encourages students to start their own business: "Participants are taught the practical skills required for small business set-up and management, and the courses are often geared toward the preparation of a business plan" (Henry et al., 2005 p. 102.). Education in enterprise "deals with management training for established entrepreneurs and focuses on ensuring the growth and future development of the business" (p.102).

Hills (1988) surveyed 15 entrepreneurship educators in the U.S. to identify which objectives in entrepreneurship education they pursue. Hills (1988) found that entrepreneurship educators propose two major objectives: (a) increase awareness of entrepreneurship as a career option and (b) increase understanding of the process of creating a new business.

Based on a survey of deans at 750 business schools and 226 engineering schools, (Vesper \& Gartner, 1997) summarized descriptions of courses at 177 four-year colleges and universities both inside and outside the U.S. Vesper and Gartner (1997) found that the standard entrepreneurship course in 1994 used teaching methods such as case studies, speakers, lectures, texts, and the writing of venture plans, both individually and as a team, often followed by judging panels including outside professionals for continual feedback (Vesper \& Gartner, 1997).

Garavan \& O'Cinneide, (1994) posited that the teaching goals for entrepreneurship education should be to undo the risk-adverse bias of analytical techniques, develop empathy for the unique aspect of entrepreneurship, encourage a positive attitude toward change, and stimulate entrepreneurial intention. Garavan and O'Cinneide (1994) differentiated between education for business creation and education for existing business. In regards to education for existing business, three subtypes of business education can be distinguished: (a) small business awareness, which aims to increase the number of people who are sufficiently knowledgeable about small business to consider it an option at some point in life;

ISSN: 07 I8-2724. (http://www.jotmi.org)

Journal of Technology Management \& Innovation (c) Universidad Alberto Hurtado, Facultad de Economía y Negocios. 
(b) small business education, which aims to provide practical help to those seeking to make the transition toward self-employment; and (c) continuing small business education, which is designed to enable people to enhance and update their skills to run a business (Garavan \& O'Cinneide, 1994). Béchard and Toulouse (1998) identified four types of general teaching goals for entrepreneurship education: (a) entrepreneurship awareness, (b) business creation, (c) small business development and (d) training of trainers. Programs seeking to create entrepreneurship awareness provide general information about entrepreneurship and ask the audience to reflect on entrepreneurship as a career. Business creation programs train students in technical, human, and managerial skills to create a business. Small business development programs usually are created to match specific learning needs of small business owners. Training of trainers' type of programs teaches educators skills to do consulting, education, and follow up of small business.

Little consistency about what goals they should accomplish was found on the literature about entrepreneurship. Most instructors reporting their teaching activities in scholarly literature do not state what they are trying to accomplish through their classes. Even though previous work in entrepreneurship education has pointed out the existence of several possible teaching goals in entrepreneurship courses (i.e. Béchard and Toulouse, 1998; Garavan \& O'Cinneide, 1994; Hills, 1988), most articles within the topic simply describe what they did without further consideration of the goals behind the teaching activities described (e.g Rae \& Craswell, 2000; Cope, 2003; Rae, 2004; (Shepherd, 2004)).

In 1994, a research project sponsored by the Kauffman Foundation, surveyed a panel of 170 firms (making between five and twenty million in sales) about what the learning needs of entrepreneurs are at different stages of the venture. This study sought to know what kind of practical knowledge was useful to run a business. Entrepreneurs were asked to rank, from one (least) to seven (most), the importance of four type of content: (a) finance, (b) marketing, (c) human resources and (d) growth management. The results yielded the following average needs: finance (5.193), marketing (4.857), human resources (4.876) and growth management (4.739) (Sexton, Upton, Wacholtz, \& McDougall, 1997).

There are some studies (i.e., Finkle 2006; Solomon 2007) that depict what is the state of the art in entrepreneurship education. In 2006, Finkle surveyed 94 entrepreneurship programs across the U.S. asking what courses were included in their programs. Finkle (2006) found that $39 \%$ of the entrepreneurship programs surveyed offered a course called Business Plan Development, 33\% offered Introduction to Entrepreneurship, 22\% Entrepreneurial Finance, and 12\% Entrepreneurial Marketing. While the Business Plan class was taught at most entrepreneurship programs, there is still a question about whether the contents under that course's name were similar across instructors. A Business Plan Development course is designed to help students to develop an effective written implementation plan for a new business venture. The course deals, in general, with the critical decisions and actions that entrepreneurs must make in both planning and executing a new venture (Finkle, 2006).

\section{Results}

Syllabi, transcripts, and the Teaching Goals Inventory (TGI) provided data to explore the types of goals instructors try to accomplish and what might be related to their teaching choices. The TGI categorizes teaching goals into six goal clusters: (a) higher order thinking skills, (b) basic academic success skills, (c) discipline specific knowledge and skills, (d) liberal arts and academic values, (d) work and career preparation, and (e) personal development.

The TGI is an instrument designed to identify the teaching goals that instructors consider essentials for a specific course.TGI scores provided evidence to suggest that entrepreneurship instructors present some consistency in their preferred teaching goals. Higher order thinking skills and leadership were the teaching goals that instructors reported most important for their classes. The higher order thinking skills' cluster focuses on developing students' abilities to synthesize and integrate information and ideas to solve problems (Angelo \& Cross, 1993). This cluster refers principally to problem solving skills and it will be labeled as the problem solving cluster. The work and career preparation cluster refers to the student's ability to work with others productively. Skills such as "develop leadership skills," "improve ability to organize and use time effectively", "develop management skills" or "develop a commitment to personal achievement" are some of the items in this cluster (p. 21). Since the work and career preparation cluster refers to management skills, it will be identified through this article as managerial skills.

After a general view of what goals instructors rated as more important, different grouping were tested to check if specific groups of instructors might look notoriously similar or different in term of preferred teaching goals. After grouping instructors by teaching appointment, academic background, and similar levels of teaching experience, it was found that similar preferences of teaching goals could be observed. Based on TGI scores, instructors with teaching appointments in business schools as well as instructors with more teaching experience had similar teaching goals. Instructors at business departments preferred goals related to managerial skills and problem solving while instructors teaching at engineering schools considered problem-solving skills as more important. 
Problem solving skills and managerial skills were the two clusters that received more preferences by the instructors studied. However, instructors teaching at engineering school did not emphasized managerial skills as much as business instructors did. It seems that, some instructors provided a slightly different entrepreneurship education than others.

For instance, Daniel and Ken who taught in a business school at the time of the interview in 2010, used to teach in engineering schools. Daniel and Ken reported to emphasize different teaching goals at engineering schools adapting their goals to the interest and capacities of the students.

[My former institution was] an engineering school, and so many [students] came into the class with the germ of an idea, but they didn't know think about commercializing it or monetizing that idea, and so, a lot of what I focused on at the entrepreneurship class at $x x x x$ Tech is how you turn an opportunity, how you think of it from a commercialization standpoint. So, how do you take it from this idea of this geek technology to thinking about how do we really build a business around that? (Daniel, 748-754)

I mean I would say one thing about [my current students], again, goes a little bit away from my background is they're less focused on technology than other students l've had at $x x x x x x$ or at $x x x x x$ just because of their background and the things they are interested in. They don't typically -- I haven't been able to get them real excited about technology ventures. They're mostly looking at sort of service ventures that you might expect [in this city] type of market (Ken, 26I-266).

Daniel and Ken modified their teaching goal depending on the characteristics of the students being trained. When analyzed the data related to Bob and Hector, it is possible to note that they teach different that the rest of the group. Bob and Hector teach similar to what Daniel and Ken used to do at engineering schools. That is to say, an education more centered on business creation in contrast to an education more centered on an entrepreneurial mindset.

Some instructors in the sample, such as Kathy and Donna did not tie entrepreneurship education to the action of business creation as, for instance, Bob and Hector did. Bob and Hector, the two instructors teaching engineering students, reported that starting a real company was part of the course' goals. The rest of the professors did not included on their syllabus a real business creation. Hector 'syllabus included as a goal: apply venture opportunity screening techniques to an actual start-up idea, and Bob' syllabus included: Those with ideas will learn how to attract a team and turn ideas into reality.
Scored on the TGI also showed that teaching experience and teaching appointment related to the type of goals that instructors preferred. It seems that as instructors assume more responsibilities in teaching entrepreneurship they train themself to learn how and what to teach. More experienced instructors had participated more in students business plan contest and knew better the specialized website in the field (i.e. Kauffman Foundation, GEM, Stanford e-corner). In the process of looking for information about how to teach entrepreneurship, instructors adopt similar teaching practices that other colleges nationwide.

In regards of teaching appointment, this might be related to teaching goals because instructors adapt their goals to the type of students they teach. For instance, if instructors believed that students' learning needs were to success within the corporate world, then they received a more inspirational education. On the contrary, if students showed high potential to become entrepreneurs soon, then instructors focused more on real business creation. The entrepreneurship education focused on business creation had as a final teaching goal to evaluate ideas and leverage resources to start a business. The inspiration type of entrepreneurship education focused on how to think entrepreneurially in any thing the students does.

\section{Across Case Analysis}

The raw data for each group was analyzed. The goal was to understand instructors' selection of teaching goals. To come up with finding a codebook was developed and each codes was reviewed case by case and across case.Two major themes were identified after the coding and the subsequent analysis: (a) entrepreneurship education is not only about business creation, and (b) learning needs determine teaching goals. The following section explains each theme and develops some implications.

\section{Entrepreneurship education is not only about business creation}

Teaching goals in this group of instructors can be divided in two: (a) business creation or (b) inspiration. Whether instructors teach one or another depend on the audience they are training. If professors identify potential in the student business idea, they conceived the business plan and its implementation as the final goal of the course. If professors consider that the students' insights do not have the potential to create value for the society they use business creation as a mean to develop entrepreneurial skills. For some professors, the creation of a business is a major product of their courses. For others, the creation of a business is the mean to develop entrepreneurial skills. Daniel, Hector, Bob, and Ken, when teaching to students whose insight have potential to become a real business, their teaching goal was to craft a

ISSN: 07 I8-2724. (http://www.jotmi.org)

Journal of Technology Management \& Innovation (C) Universidad Alberto Hurtado, Facultad de Economía y Negocios. 
plan for a real business. When working with undergraduate students whose more possible future will be to work for a large corporation the teaching goal became to increase students' self-confidence to create value and legitimize entrepreneurship as a possible career path.

Daniel and Ken raised as a theme the fact that business schools prepare people for the corporate world more than anything else. Some of the students that take entrepreneurship classes may start a business, but not soon after graduation. Therefore, these instructors adopt a different angle for entrepreneurship education. As important as starting a business, entrepreneurship courses is an opportunity to integrate others' disciplines, such as finance, marketing and general management. Entrepreneurship courses also offer a window to teach how to manage organizations in the hectic business environment of the 2 I st century. In addition to that, entrepreneurship education is the opportunity to show that entrepreneurship can be a legitimate path in the future. This is Daniel view of entrepreneurship education.

At the undergraduate level, it's much more inception. It is I think first and foremost to help them see entrepreneurship as a legitimate career path. Because when they're taking their accounting classes and they're taking their financial classes, primarily all that they get with this corporate life, corporate work and that's the only legitimate career. That you go to work for a bank. You go to work for a Fortune 500 company. In the entrepreneurship classes, I want them to come out of the class understanding that entrepreneurship is a legitimate career path. And that while they may go work in the corporate world for four, five, or six years, that it is very legitimate for them to have a long-term life plan that at some point they will focus on starting their own businesses (Daniel, 599-617).

The following quote reflected Ken's answer to the question about what were his learning outcomes.

So to me, the balance with all these courses is giving them some pragmatic skills that they can actually use particularly because they're seniors and they are going out into the world. So in a way, we're trying to apply all the different things they've learned up until this point which I think is appropriate particularly for these capstone experiences (Ken, 30I-305).

As we can see in Ken's quote, and in the following quote from Daniel, these instructors were equally concerned for the future performance of their students as employees as well as entrepreneurs.

On the other hand, Hector prepares a class thinking in high potential entrepreneurs. "So what they are looking for in those courses is building a business around new technological development and not looking at somebody who wants to start a sandwich shop" (Hector, 96-I04). Hector sought for students who want to be entrepreneurs "if you think you might want to be an entrepreneur, this is the course that you would take" (Hector, 252) although he might have some who "take the elective because it fits with their schedule" (Hector, 262).

Daniel, Donna, and Ken taught entrepreneurship expecting to help students perform better in the corporate world. These instructors did not understand entrepreneurship education necessarily as a business creation. Entrepreneurship for them was something beyond than starting a business; it was the opportunity to integrate the different disciplines of management and learn to think as an entrepreneur, which is not the same as founding a company. Hector and Bob were more pragmatic. Bob taught what students need to start their business or to perform better as business founders. To do that, Bob engaged alumni entrepreneurs or local entrepreneurs who could teach the topics students needed to learn. Bob was teaching students how to create businesses.

We try to focus the class on students who either have identified a problem but are looking for a team to help them find the solution or that have an idea and don't know how to evaluate different possible ways of building business around it (Bob, 98-107)

The analysis showed two types of teaching goals. Some instructors expect to teach students how to start a business, others how to develop entrepreneurial skills to perform better in the corporate world including skills such as creativity and leadership.After identifying these types of teaching goals, the question became about what makes instructors to emphasize a specific teaching goal within an entrepreneurship course. One important factor influencing the type of goals that this group of instructors pursued was the student learning needs.

\section{Students'learning needs}

Instructors' teaching goals can be reviewed in the light of the students demand for entrepreneurship education: there are students seeking to learn how to think entrepreneurially to succeed the corporate world and students seeking to become self-employed. Between the groups who want to become self-employed there are high potential entrepreneurs (eventually serial entrepreneurs) and life style entrepreneurs. Donna did not seem to be teaching high tech entrepreneurship because her students were not great in technology nor had the experience to start a business soon after graduation. Daniel, Ken, and Mary were teaching entrepreneurship to students who most probably would go to the corporate 
world for six or seven years before to eventually become entrepreneurs. Selma and Kathy were not teaching business creation but other important skills that entrepreneurs seem to have (creativity and leadership). Bon and Hector were teaching high potential entrepreneurship.

Ken referred to the different types of entrepreneurship students he has had along their career and how he adjusted to those different realities.

I mean I would say one thing about my current students, again, goes a little bit away from my background is they're less focused on technology than other students l've had at University A or at University B just because of their background and the things they are interested in. I haven't been able to get them real excited about technology ventures (Ken, 26I-266).

Ken modified their teaching goal depending on the characteristics of the students. Students' learning needs were identified as the most important influencer of instructors teaching goals. Instructors adapted their goals to the students' learning needs. For instance, if instructors believed that students would work in the corporate world, then their focus in the entrepreneurship curriculum was on general skills teaching--those skills that entrepreneurs have that make a positive difference for a corporate executive. On the contrary, if the instructor believed that students were interested in starting a real company if they had the chance to do it, the course focused on planning the business and meeting potential investors.

Daniel and Ken, while teaching to high tech students focused on business creation. But later in their careers, while teaching undergraduate business students, they focused more on entrepreneurial thinking and people skills. Ken distinguished between engineering and business students: engineering students are more creative and business students more pragmatic. Engineers and managers need different emphasis in entrepreneurship education. "Tech students can be very creative in terms of the technology and everything, but they don't really understand the pragmatic aspects of how you go about turning some cool technology into a real business" (Ken, 637). Business students, however, understand the process of building an organization because they have taken finance, marketing, and accounting courses.

Ken pointed out a self-selection process between who decides to major in business as an undergraduate. If someone has skills like being great at technology, math, or science, they will major in one of those things. The ones who want to major in business tend to be kids that do not have one of those particular skills or they are not great web designers or good at computer coding but they are smart. They are motivated. They want to get a good job so they tend to be more pragmatic. They are more practical. Ken believes that creative people tend to go in creative areas where they can do creative things and people that are more pragmatic end up majoring in more pragmatic things.

Daniel and Ken emphasized different teaching goals at engineering and business schools, adapting their goals to the interests and capacities of the students. Bob and Hector had similar goals to those Daniel and Ken used to have at engineering schools. Kathy and Donna, on the other hand, never tied entrepreneurship to business creation.

\section{Findings and Discussion}

Business creation and general entrepreneurial skills were found to be the extreme of a continuum where many teaching goals may fall in between. Business creation had as a major goal learning how to evaluate ideas and leverage resources to start a real business. General management and people skills were targeted to teach how to think entrepreneurially in anything a person does.

Instructors select teaching goals by paying attention primarily to the learning needs and interests of the students. For some instructors, the students taking entrepreneurship classes will enter the corporate world soon after graduation. For them, instructors seek to develop an entrepreneurial mindset that helps to succeed in the corporate world. Other groups of students have the interests and abilities to become business founders. For this group, instructors seek to help them to start their own business.

To become entrepreneurs, individuals need two type of knowledge: a breadth of knowledge about business and a depth of knowledge about a technical discipline (HampdenTurner, 2010; Seelig, 2010). This is what McKinsey (2010) has defined as the T-shaped people. A technical specialization that has been developed mainly through undergraduate education is complemented by the horizontal appreciation and understanding of other disciplines and a professional context. Through postgraduate degrees and early career experience, an appreciation and understanding of other disciplines is often developed.Tim Brown, CEO of design firm IDEO described this ideal employee as a "specialist with a passion and empathy for people and for other subject areas" (HEFCE, 20I0, p. I4). High impact entrepreneurs manage the technique (or know-how related to an industry) and the skills to enact a vision that brings the benefit of that technique or know-how to the people. The professional that becomes an entrepreneur is a type T professional (Seeling, 20II; McKinsey, 20I0). A breath of knowledge about business composes the horizontal part of the $T$, and a depth of knowledge in a technical discipline composes the vertical part of the T. 
The instructors studied suggested that entrepreneurship education complements the technical knowledge of high technology students. Through entrepreneurship education, high technology students became, to some extent, Tshaped professionals. Undergraduate business students, on the other hand, become T-shaped professionals after early career experiences. Most undergraduate business students will need 6 or 7 years of work experience before they have a serious chance of succeeding as entrepreneurs. In contrast, MBA students or graduate students who already have that experience may have the real opportunity to start a business during their graduate education. Once you are a T-shaped professional, an entrepreneurship class could be a natural place to give serious thought about starting a company.

This study suggests that, entrepreneurship instructors, conscious about the work experience needed by most undergraduate students, adapt their teaching goals to inspire them, hoping they gain experience to become entrepreneurs someday. In this sense, business and technology students may have a slightly difference, Technology students may have the technical skills to overcome some market barriers of entries. For them, entrepreneurship education becomes the basis to develop the general business skills needed to create a business around those technical skills.

In consequence, this study suggests that there is not one type of entrepreneurship education; at least two types of entrepreneurship education were identified: (a) student centered and (b) business centered. A student centered entrepreneurship education is targeted to students that are preparing to go to the corporate world. Business centered entrepreneurship education is targeted to those who need to go through the process invention-innovation to a business.

Business and engineering students usually have different career paths. Business students are trained to become functional managers (Dyer, Gregersen, \& Christensen, 2008) and most of them will spend their careers as such. Engineers are trained to apply engineering sciences to the improvement of products and processes. As such, they will have chances to start businesses in more innovative industries, with less competition and higher chances to succeed. U.S.born technology company founders tend to have diverse educational backgrounds but the largest group (55\%) had terminal degrees in STEM-related fields (science, technology, engineering, and mathematics), and $33 \%$ had degrees in business, finance, and accounting (Wadhwa \& Freeman, 2010). Therefore, engineers are more likely to start a business than undergraduate business students are. Entrepreneurship instructors should consider this reality when selecting teaching goals for entrepreneurship education. The learning needs of students who take a 3-credit course because of schedule convenience would be very different than students who think have a good product and take an entrepreneurship class for the sake of learning whether they could launch a business.

\section{Implications for practice}

This study was designed to understand instructors' perspectives and actions related to their teaching goals. Results suggest that the group of instructors studied pursued two types of profoundly diferent teaching goals. Some of them were trying to teach how to start a sucessfully business while another group was trying to develop entrepreneurial skills. Those two tyopes of teaching goals have imporrtant implications in terms of pre selection of students, the mandatory or voluntary character of the curriculum, and type of teaching methods used. For instance, if the goals is to create business students selected should be those with ideas with high potential of sucess, the regimen should be voluntary (some people may legimitately want to be a great employee), and business plan as teaching methods would be a mean rather than an end. 


\section{Referencias}

ACS,Z. (2002). Entrepreneurial Activity and Economic Growth: An Empirical Analysis. Kaufman Foundation. Retrieved from http://scholar.google.com/scholar?hl=en\&btnG $=$ Search\&q=intitle:Entrepreneurial+Activity+and+Economic +Growth+:+An+Empirical+Analysis\#0

AL-LAHAM,A., Souitaris, V., \& Zerbinati, S. (2007). Do entrepreneurship programmes raise entrepreneurial intention of science and engineering students? The effect of learning, inspiration and resources. Journal of Business Venturing, 22(4), 566-59l.

ANGELO,T.A., \& Cross, . K.P. (1993). Classroom assessment techniques: A handbook for Teachers (2nd ed.). San Francisco: Jossey-Bass.

BÉCHARD, J., \& Toulouse, J. (1998). Validation of a didactic model for the analysis of

training objectives in entrepreneurship. Journal of Business Venturing, I3(4), 317-332.

BECHARD, J., \& Gregoire, D. (2005). Entrepreneurship Education Research Revisited:

The Case of Higher Education. Academy of Management Learning \& Education, 4(I), 22-43.

BERG, B. (200I). Qualitative Research Methods for Social Sciences (4th ed.). Massachusetts: Pearson.

BRANNBACK, M., \& Carsrud, A. (2009). Understanding the entrepreneurial mind: opening the black box. Retrieved from http://books.google.com/books?hl=es\&lr=\&id=4j9SNJwLSsC\&pgis= I

BRUSH, C., Manolova,T. S., \& Edelman, L. F. (2008). Separated by a common language? Entrepreneurship research across the Atlantic, 32(2), 249-266. Retrieved from http://onlinelibrary.wiley.com/doi/I0. I I I I/j. I540-6520.2007.00225.x/full

CARAYANNIS, E., Evans, D., \& Hanson, M. (2003). A crosscultural learning strategy for entrepreneurship education: outline of key concepts and lessons learned from a comparative study of entrepreneurship students in France and the US. Technovation, 23(9), 757-77I. Retrieved from http:// www.sciencedirect.com.ezproxy.fiu.edu/science/article/pii/ SOI 66497202000305

CONE, J. (2008). Teaching entrepreneurship in colleges and universities: How (and why) a new academic field is being built. Retrieved October 27, 201 I, from http://www.kauffman.org/items.cfm?itemID=716
COOPER, S., Bottomley, C., \& Gordon, J. (2004). Steeping out of the classroom and up the leader of learning: an experiential learning approach to entrepreneurship education. Industry and Higher Education, I8(I), I I-22.

DICKSON, P., Solomon, G. T., \& Weaver, K. M. (2008). Entrepreneurial selection and success: does education matter? Journal of Small Business and Enterprise Development, I5(2), 239-258. doi:I0.I |08/|462600081087|655

DYER, J. H., Gregersen, H. B., \& Christensen, C. (2008). Entrepreneur behaviors, opportunity recognition, and the origins of innovative ventures. Strategic Entrepreneurship Journal, 2(4), 317-338. doi:10.1002/sej

FIET, J. O. (2000). THE PEDAGOGICAL SIDE OF ENTREPRENEURSHIP THEORY. Journal of Business Venturing, I6, $101-117$.

GARAVAN, T. N., \& O'Cinneide, B. (1994). Entrepreneurship Education and Training Programmes:: A Review and Evaluation - Part 2. Journal of European Industrial Training, 18(I I), |3-2|. doi: |0.| |08/030905994|0073505

GIBB, A. (2002). of a new enterprise and entrepreneurship paradigm for learning: creative destruction, new values, new ways of doing things and new combinations of knowledge. International Journal of Management Reviews, 4(3), 233-269. Retrieved from http://onlinelibrary.wiley.com/ doi/I0.1 I I I/I468-2370.00086/abstract

GREEN, P., \& Rice, M. (2007). Entrepreneurship Education (p. 543). Boston, MA: Edward Elgar Pub. Retrieved from http:// www.amazon.com/Entrepreneurship-Education-International-Library/dp/ / 845424220

JAMIESON, I. ( 1 984), "Schools and enterprise," in Watts,A.G. and Moran, P. (eds). Education for Enterprise, CRAC, Ballinger, Cambridge, MA.

HILLS, G.E. (1988). "Variations in university entrepreneurship education: an empirical study of an evolving field, Journal of Business Venturing 3 (I) 109-22.

FINKLE, T. Kuratko, D, \& Goldsby, M. (2006). An Examination of Entrepreneurship Centers in the United States: A National Survey. Journal of Small Business Management, 44(2), 184-206

JONES, C. (2007). Developing the enterprise curriculum Building on rock, not sand. Industry and Higher Education, $2 \mathrm{I}(6), 405-4 \mathrm{I}$. Retrieved from http://www.ingentaconnect. com/content/ip/ihe/2007/0000002 I/00000006/art00004 
KURATKO, D. F. (2005). The emergence of entrepreneurship education: Development, trends, and challenges. Entrepreneurship Theory and Practice, 29(5), 577-598. Retrieved from http://onlinelibrary.wiley.com/doi/l0.1 II I/j.15406520.2005.00099.x/full

MERRIAM, S. B. (2002). Qualitative research in practice: Examples for discussion and analysis. San Francisco:Jossey-Bass.

PATTON, M. (200I). Qualitative Research \& Evaluation Methods (3rd ed.).Thousand Oaks, California: Sage Publications.

PHAN, P., \& Foo, M. (2004). Technological Entrepreneurship in Emerging Regions. Journal of Business Venturing, 19, I-5.

READER, D., \& Watkins, D. (2006). The Social and Collaborative Nature of Entrepreneurship Scholarship: A Co-Citation and Perceptual Analysis. Entrepreneurship theory and practice, 30(3), 4I7-44I. Retrieved from http://onlinelibrary. wiley.com/doi/I0.1 I I I/j.1540-6520.2006.00 I27.x/full

REYNOLDS, P., Bosma, N., Autio, E., Hunt, S., De Bono, N., Servais, I., Lopez-Garcia, P., et al. (2005). Global Entrepreneurship Monitor: Data Collection Design and Implementation 1998?2003. Small Business Economics, 24(3), 205-23I. doi:|0.|007/s| | |87-005-|980-|

RAE, D., \& Carswell, M. (2000). Using a life-story approach in researching entrepreneurial learning: The development of a conceptual model and its

implications in the design of learning experiences. Education \& Training, 42(4/5), 220-228.

RAE, D. (2003). Opportunity centered learning: an innovation in enterprise education?

Education \& Training, 45(8/9), 542-549.

RAE, D. (2005). Entrepreneurial learning: a narrative-based conceptual model. Journal of Small Business and Enterprise Development, 12(3), 323- 335.

SEXTON, D.L. and Bowman, N.B. (1984). "Entrepreneurship education: suggestions for increasing effectiveness," Journal of Small Business Management, 22 (4) |8-25.

SEXTON, D. L., Upton, N. B., Wacholtz, L. E., McDougall, P.P. (1997) "Learning Needs of Growth-Oriented Entrepreneurs", Journal of Business Venturing, I-8.

SHEPHERD, D. A. (2004). Educating Entrepreneurship Students About Emotion and Learning From Failure. Academy of Management Learning \& Education, 3(3), 274 -287.
VAN DER SLUIS, J., Van Praag, M., \& Vijverberg, W. (2008). Education and entrepreneurship selection and performance: A review of the empirical literature. Journal of Economic Surveys, 22(5), 795-84I.

VESPER, K. H., \& Gartner, W. B. (1997). Measuring progress in entrepreneurship education. Journal of Business Venturing, |2, 403-42|.

VON GRAEVENITZ, G., Harhoff, D., \& Weber, R. (2010). The effects of entrepreneurship education. Journal of Economic Behavior \& Organization, 76(I), 90-112. doi:10.1016/j. jebo.2010.02.015

WADHWA, V., \& Freeman, R. (2010). Education and tech entrepreneurship. Innovations: Technology,, 5(2), |4|-|53. Retrieved from http://www.mitpressjournals.org/doi/ abs/I0.1162/inov_a_00018

WEAVER, M., Dickson, P., \& Solomon, G. (2005). What is Known and Not Known about the Links Between Education and Entrepreneurial Activity. The Small Business Economy for Data Year 2005:A Report to the President (Pp. I 13-156). Washington, DC.

YIN, R. K. (2003). Case study research design and methods. Thousand Oaks, California: Sage Publications. 